\title{
The role of ethnozoology for the mammal conservation of the Brazilian Cerrado
}

O papel da etnozoologia para a conservação de mamíferos do Cerrado brasileiro

\author{
A. M. Vidica-Oliveira ${ }^{1,2} ;$ W. Hannibal ${ }^{1,2^{*}}$

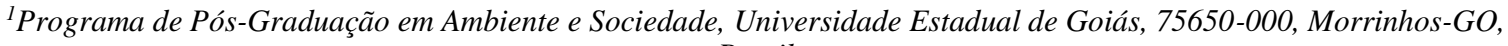 \\ Brazil \\ ${ }^{2}$ Laboratório de Ecologia e Biogeografia de Mamíferos, Universidade Estadual de Goiás, 75860-000, Quirinópolis- \\ GO, Brazil
}

*wellingtonhannibal@gmail.com

(Recebido em 23 de outubro de 2020; aceito em 18 de janeiro de 2021)

\begin{abstract}
In this study, we investigated the ethnozoological practices adopted by the population of the São Domingo dos Olhos D'Água (SDOA) settlement for the conservation of mammals in a fragmented landscape of the Cerrado, southern Goiás State, Brazil. Initially, we surveyed the mammal fauna in the legal reserve areas of SDOA through the active search and interview. Subsequently, we applied socioeconomic and ethnozoological questionnaires to 30 people to investigate the association of these two approaches in mammal conservation. We found 14 species of large and medium-sized mammals (5 threatened species) in the SDOA settlement. More than $90 \%$ of the interviewees have a low level of scholarly education, aged between 45 to 77 years, with agriculture and livestock as their main economic activity. All interviewees have lived in the area for more than 10 years, and $67 \%$ said they do not fish and $90 \%$ do not hunt. The inhabitants of the SDOA know its mammal fauna, regardless of scholarly education or hunting and fishing practice. On the other hand, monthly income and residence time at the settlement are socioeconomic factors that affected the degree of perception about the mammals. Ethnozoological studies associated with socioeconomic factors are an important approach in predicting knowledge about local biodiversity.
\end{abstract}

Keywords: monthly income, residence time, socioeconomics

Neste estudo, investigamos as práticas etnozoológicas adotadas pela população do assentamento São Domingo dos Olhos D'Água (SDOA) para a conservação de mamíferos em uma paisagem fragmentada do Cerrado, no sul do estado de Goiás, Brasil. Inicialmente, realizamos levantamento da fauna de mamíferos nas áreas de reserva legal da SDOA por meio de busca ativa e entrevista. Posteriormente, aplicamos questionários socioeconômicos e etnozoológicos a 30 pessoas para investigar a associação dessas duas abordagens na conservação de mamíferos. Encontramos 14 espécies de mamíferos de grande e médio porte (5 espécies ameaçadas) no assentamento SDOA. Mais de $90 \%$ dos entrevistados têm baixo nível de escolaridade, idade entre 45 e 77 anos, tendo a agricultura e a pecuária como principal atividade econômica. Todos os entrevistados residem na área há mais de 10 anos, sendo que 67\% disseram que não pescam e $90 \%$ que não caçam na área. Os habitantes do SDOA conhecem sua fauna de mamíferos, independentemente da formação escolar ou da prática de caça e pesca. Por outro lado, a renda mensal e o tempo de residência no assentamento são fatores socioeconômicos que afetam o grau de percepção sobre a fauna. Estudos etnozoológicos associados a fatores socioeconômicos é uma abordagem importante na predição do conhecimento sobre a biodiversidade local.

Palavras-chave: renda mensal, tempo de residência, socioeconomia

\section{INTRODUCCION}

In recent years, there has been a growing concern about the anthropogenic effects on the conservation of biodiversity and ecosystem services [1-4]. The rapid human population growth driving widespread agricultural expansion has been the worst scenario for local and global biodiversity [2]. In this scenario, human land use has consistently negative impacts on biodiversity through habitat loss, fragmentation, fires, roadkill, and hunting $[1,2]$. Thus, understanding the "making use" and "conservation" of natural resources, even yet in local communities, should be priority for biodiversity and ecosystem services conservation. 
Ethnozoological studies can be a valuable asset to increase our understanding of the cultural, economic, social, and traditional roles played by animals. Thus, they have a central part in conservation and management of local biodiversity, adding contexts of local human communities [5-7]. In this sense, local ecological knowledge and the conservation of forest biodiversity are linked through various geographical, social, economic, cultural and belief aspects; in addition to empirical knowledge about the functions and benefits of the ecosystem [8]. However, local ecological knowledge faces a challenge in combining traditional knowledge of local populations with scientific knowledge [8], as well as ethnozoology that seeks to advance the methodological, taxonomic procedures and use of quantitative techniques [9].

Brazil is a continental and megadiverse country [10], shown a human population density, socioeconomic patterns [11], and biodiversity [12] heterogeneously distributed. Approximately, $40 \%$ of native vegetation coverage in Brazil is found in 400 municipalities that represent $7 \%$ of the municipalities in the country. This native coverage is distributed in the Amazon, northeastern Cerrado and Caatinga domains, specifically in north and northeastern region, where $13 \%$ of the most economically underprivileged Brazilians live. Historically, replacing forests with agropastoral activities has not resulted in a significant increase in the human development index (HDI) of individuals living there, which exacerbates the rural exodus [13]. However, land use change will continue be the primary driver for the loss of biodiversity and ecosystem services and will be a key factor during most of the $21^{\text {th }}$ century. In recent years, forest losses in the country were at least three times greater than the restoration promised area, particularly in the Cerrado, the conversion of natural ecosystem remains high $\left(236,000 \mathrm{~km}^{2}\right.$ between 2000 and 2015) [13].

The Cerrado is one of the 34 Global hotspots of biodiversity [14] severely threatened by agriculture and other anthropogenic practices, therefore, a priority domain for establishment of studies regard to the conservation of species, in order to aggregate knowledge on ecological and ethnozoological aspects [15]. The Cerrado harbor 251 mammal species [16], 22 endemic and 6 threatened species [17]. Although the importance of ethnozoological studies to the maintenance of the Cerrado biodiversity, there are scarce information [9], which highlights the need to raise the discussions in order to reduce the negative impacts on natural resources [18]. Thus, the folk knowledge about Cerrado mammal fauna is the first step to understand the existing relationships between the community and the local environment, and a crucial device for the biological conservation of a locality [19]. In this scenario, the challenges for ethnozoology are still many [6, 9], but should be investigated in the perspective of each phytogeographic domain, due to its rich biodiversity as well as its specific socioeconomic and cultural characteristics.

In this study, we investigate the role of ethnozoology in the conservation of Cerrado mammals in central Brazil. For this, we investigated the association between mammal fauna, socioeconomic and ethnozoological parameters of the residents of the São Domingos dos Olhos D'Água (SDOA) settlement, in the municipality of Morrinhos, southern Goiás State. Our main questions were: i) What are the large and medium sized mammal species in the settlement? ii) How population interacts with its local fauna and what is perception degree about mammal presence? iii) Is there a relationship between perception degree on mammal presence and the socioeconomic patterns of the population?

\section{MATERIAL AND METHODS}

\subsection{Study area}

The SDOA settlement is located in southwestern of the municipality of Morrinhos, in the southern mesoregion of the state of Goiás, in central Brazil (Figure 1). This settlement is a result of the incursion of landless rural workers, who claimed ownership of a farm, with identical name, declared unproductive [20]. According to data from the Instituto Nacional de Colonização e Reforma Agrária (INCRA), the settlement was created on 01/27/1999 with an area of 3448.6 hectares, divided into 86 lots of different sizes. According to Memorandum No. 830/97/SR-Z, the protected area (PA) of SDOA, legal reserve range about 790 hectares and the Permanent 
Preservation Area is about 62 hectares [20]. Although SDOA settlement harbors $~ 250$ inhabitants, it does not have school support, and thus there is no school and transport for students.

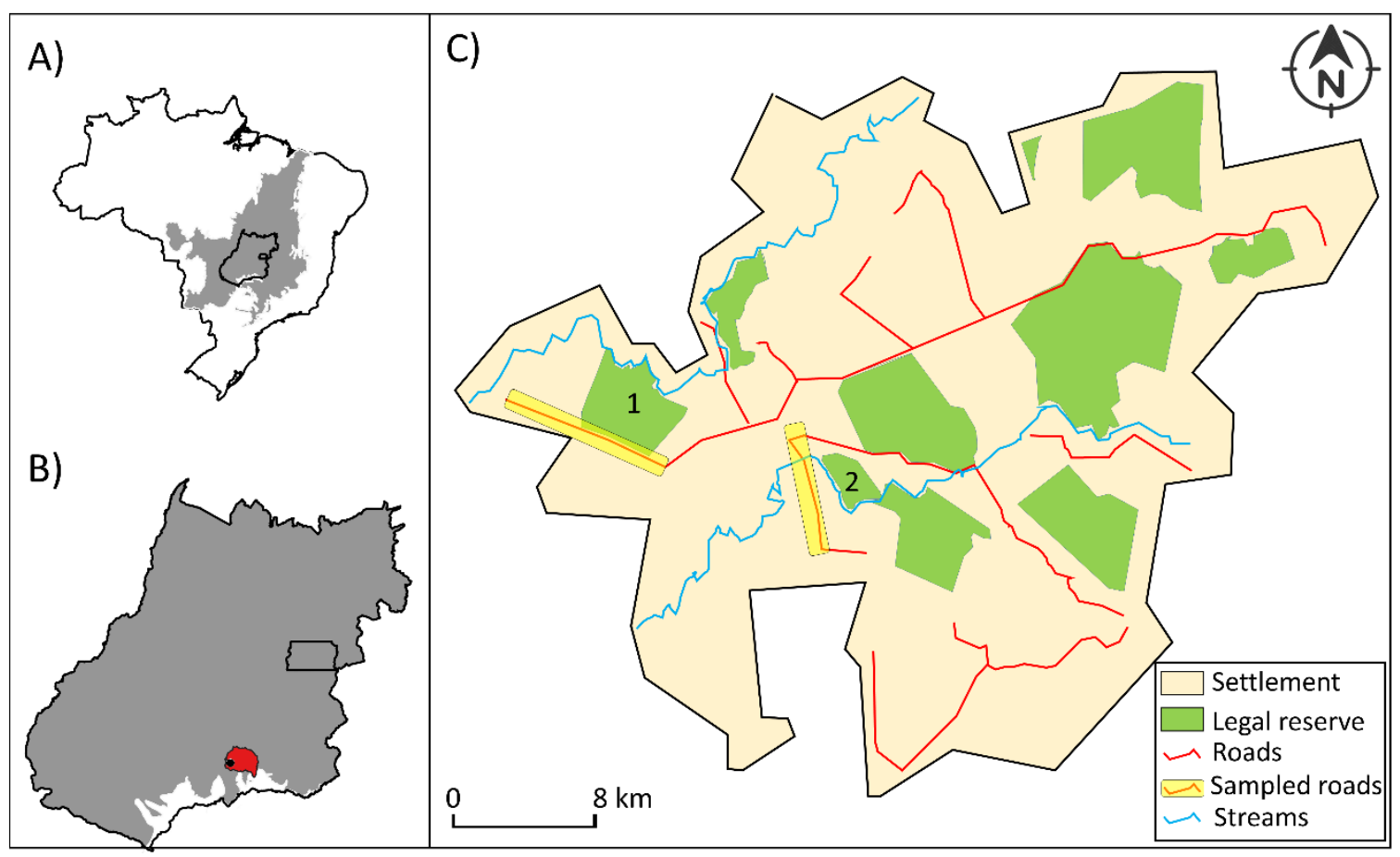

Figure 1: A) Map showing Cerrado [dark gray] in Brazil. B) Goiás State, with Morrinhos municipality in red highlighted settlement black point. C) São Domingos dos Olhos D'Água settlement highlighted the legal reserves (sampled reserve: 1 and 2), roads and streams.

\subsection{Sampling of large and medium-sized mammals}

To inventory the mammal fauna of the SDOA settlement, we surveyed through activity search on two areas of legal reserve and two roads in the vicinity (Figure 1), monthly from January to September 2019. Large and medium-sized mammals were recorded by: i) visualization, ii) tracks, iii) burrows (armadillos), iv) vocalization (primates), v) feces, and vi) interviews with local residents. The sampling effort in the field comprised 1:30 $\mathrm{h}$ at each site for each sampling occasions, totaling 27 sampling hours. The tracks were photographed and identified according to the empirical basis or in accordance to field guides on mammals [21]. The species were classified as threatened according to the Red Book of the Brazilian Fauna Threatened of Extinction [22] and The IUCN Red List of Threatened Species [23].

\subsection{Socioeconomic and ethnozoological parameters}

The data collection was based on the methodology applied by Pasa 2004 [24], adjusting qualitative and quantitative aspects, involving aspects related to the socioeconomic issue of the families and contexts of the environmental perception of the interviewees, in order to designate attributes of ethnobiology. Thus, we applied two semi-structured questionnaires: a socioeconomic (Appendix 1) and an ethnozoological (Appendix 2) to 34.8\% ( $\mathrm{n}=30$ residents, being interviewed 1 adult people in each lot) of the lots. The interviews were applied to all people that accept to participate of the survey and were conducted in their home. Ethnozoological approach purpose to investigate the degree of perception about the presence of large and medium-sized mammal species, with distinct characteristics, but of common interest to people in rural areas.

All interviewees were instructed on the research, from the theme to the methodology that we used, with the Free and Informed Consent Form being exposed in a clear, succinct and simplified 
manner, authorized according to the CAAE Ethics and Research Committee number: 96862518.6.0000.8113.

\subsection{Data analysis}

To represent the mammal species of the settlement, and how they are recognized by the local population, we use qualitative (mammal composition) and quantitative descriptive statistics. To investigate the relationship between the perception of the presence of mammals and socioeconomic factors, we first tested the multicollinearity of the predictor variables (age, income monthly, number of people in the residence, number of people in the residence that contributed with monthly income and time of residence in the settlement) with Pearson's correlation, and excluded the auto-correlated variables $(r \geq 0.5)$, resulting the following variables: income monthly, time of residence in the settlement, and number of people in the residence. Subsequently, we ordered the interviewees according to the composition of mammals that they claimed to occur in the settlement area, through the Principal Component Analysis - PCA (Jaccard similarity) - through prcomp function of vegan package [25]. To compare the presence of mammals with the socioeconomic parameters, we used the first axis of the PCA (response variable) as a function of the selected socioeconomic parameters (predictor variable), with the multiple linear regression - $l m$ function. All analyzes were performed in $\mathrm{R}$ environment [26].

\section{RESULTS AND DISCUSSION}

We recorded 14 species, belonging to 12 families and 8 orders of large and medium-sized mammals for the SDOA settlement (Table 1). Maned wolf (Chrysocyon brachyurus), puma (Puma concolor), lowland tapir (Tapirus terrestris) and giant anteater (Myrmecophaga tridactyla) are nationally or globally threatened (Table 1).

Table 1. Large and medium-sized mammals recorded in the São Domingos dos Olhos D'Agua Settlement, municipality of Morrinhos, southern Goiás state, Brazil. † Species threatened in Brazil, * Species globally threatened.

\begin{tabular}{|c|c|c|}
\hline Order / Family / Species & Common name & Method \\
\hline \multicolumn{3}{|l|}{ Artiodactyla } \\
\hline \multicolumn{3}{|l|}{ Cervidae } \\
\hline Mazama sp. & Brocket Deer & Track \\
\hline \multicolumn{3}{|l|}{ Tayassuidae } \\
\hline Pecari tajacu (Linnaeus, 1758) & Collared Peccary & Interview \\
\hline \multicolumn{3}{|l|}{ Carnivora } \\
\hline \multicolumn{3}{|l|}{ Canidae } \\
\hline Cerdocyon thous (Linnaeus, 1766) & Crab-eating Fox & Visualization \\
\hline Chrysocyon brachyurus (Illiger, 1815) $\dagger$ & Maned Wolf & Interview \\
\hline \multicolumn{3}{|l|}{ Felidae } \\
\hline Puma concolor (Linnaeus, 1771) $\dagger$ & Puma & Interview \\
\hline \multicolumn{3}{|l|}{ Procyonidae } \\
\hline Nasua nasua (Linnaeus, 1766) & South American Coati & Visualization \\
\hline \multicolumn{3}{|l|}{ Cingulata } \\
\hline \multicolumn{3}{|l|}{ Dasypodidae } \\
\hline Dasypus novemcinctus Linnaeus, 1758 & Nine-banded Armadillo & Burrow \\
\hline Euphractus sexcinctus (Linnaeus, 1758) & Yellow armadillo & Visualization \\
\hline
\end{tabular}


Table 1 (continued)

\begin{tabular}{|c|c|c|}
\hline Order / Family / Species & Common name & Method \\
\hline \multicolumn{3}{|l|}{ Didelphimorphia } \\
\hline \multicolumn{3}{|l|}{ Didelphidae } \\
\hline Didelphis albiventris Lund, 1840 & White-eared Opossum & Interview \\
\hline \multicolumn{3}{|l|}{ Perissodactyla } \\
\hline \multicolumn{3}{|l|}{ Tapiridae } \\
\hline Tapirus terrestris Linnaeus, $1758 \uparrow *$ & Lowland Tapir & Visualization \\
\hline \multicolumn{3}{|l|}{ Pilosa } \\
\hline \multicolumn{3}{|l|}{ Myrmecophagidae } \\
\hline Myrmecophaga tridactyla Linnaeus, $1758 \dagger^{*}$ & Giant Anteater & Visualization \\
\hline \multicolumn{3}{|l|}{ Primates } \\
\hline \multicolumn{3}{|l|}{ Cebidae } \\
\hline Sapajus libidinosus (Spix, 1823) & Bearded Capuchin & Visualization \\
\hline \multicolumn{3}{|l|}{ Rodentia } \\
\hline \multicolumn{3}{|l|}{ Caviidae } \\
\hline Hydrochoerus hydrochaeris (Linnaeus, 1766) & Capybara & Visualization \\
\hline \multicolumn{3}{|l|}{ Cuniculidae } \\
\hline Cuniculus paca (Linnaeus, 1766) & Spotted Paca & Interview \\
\hline
\end{tabular}

The 14 mammalian species recorded belong to all orders of large and medium-sized mammals listed to the Cerrado domain [16]. These mammalian orders play a fundamental role in local biodiversity participating in ecological services that are essential to the balance of the environment such as predators and regulators of insect population, and seed dispersers [27]. Considering the interaction between animal and human, lowland tapir (T. terrestris), peccaries (Pecari tajacu and Tayassu pecari), capybara (Hydrochoerus hydrochaeris), spotted paca (Cuniculus paca), armadillos (Dasypus novemcinctus and Euphractus sexcinctus) and brocket deer (Mazama sp.) are commonly hunted. The opossum (Didelphis sp.), maned wolf ( $C$. brachyurus), monkey (Sapajus libidinosus), and puma (P. concolor) occasionally slaughter domestic or domesticated animals. The tapir, peccaries, capybara, and armadillos also cause some damage in agriculture [22, 23, 28].

All threatened species are negatively affected by habitat fragmentation. The giant anteater are threatened by fires, agriculture, livestock, deforestation, increase in the road matrix, fragmentation and habitat loss, hunting and indirect poisoning by insecticides applied to control ants and termites in planting and livestock areas [29]. The threats to the maned wolf are the disordered growth of urban centers and the consequent loss and alteration of habitat, the higher number of roadkill of young individuals, probably in dispersion phase [30]. Pumas are threatened by habitat loss and fragmentation, retaliation by farmers due to predation of domestic animals, roadkill, as well as fires in farmlands of sugar-cane plantation both in Atlantic Forest and Cerrado [31]. The main threats for lowland tapir in the Cerrado domain are habitat loss, fragmentation, low connectivity, hunt, livestock, fires, human density, monocultures, diseases caused by domestic animals, roadkill, lack of inspection in protected areas, and mining [32].

Most of the interviewees aged between 45 to 77 years, $70 \%(n=21$ people) of the family income from R\$ 1000 to 2000 Real, more than $60 \%(\mathrm{n}=18)$ have incomplete scholarly education, and $97 \%(\mathrm{n}=29)$ do not have high school complete. The predominant economic activity is agriculture and livestock (70\%), and all interviewed participants have lived in the area for more than 10 years (Table 2). 
Table 2. Socioeconomic characterization of interviewed resident in São Domingos dos Olhos D'Água settlement, southern Goiás, Brazil.

\begin{tabular}{lll}
\hline \multirow{2}{*}{ Sex } & Female & $53 \%$ \\
& Male & $47 \%$ \\
& $45-50$ & $10 \%$ \\
Age & $51-55$ & $23.3 \%$ \\
& $56-60$ & $20 \%$ \\
& $61-65$ & $16.7 \%$ \\
& $66-70$ & $13.3 \%$ \\
& $71-75$ & $10 \%$ \\
& $76-80$ & $6.7 \%$ \\
Income & $\mathrm{R} \$ 1000-1500$ & $53.3 \%$ \\
& $\mathrm{R} \$ 1501-2000$ & $16.7 \%$ \\
& $\mathrm{R} \$ 2001-2500$ & $13.3 \%$ \\
& $\mathrm{R} \$ 2501-3000$ & $6.7 \%$ \\
Education & $\mathrm{R} \$ 3001-3500$ & $0 \%$ \\
& $\mathrm{R} \$ 3501-4000$ & $10 \%$ \\
& Incomplete elementary school & $66.7 \%$ \\
& Complete elementary school & $30 \%$ \\
Economic activity & Complete high school & $3.3 \%$ \\
& Agriculture-Vegetables & $20 \%$ \\
& Agriculture-Fishing-Vegetables & $3.3 \%$ \\
& Agriculture-Livestock & $46.7 \%$ \\
Settlement time & Vegetables & $3.3 \%$ \\
& Livestock & $23.3 \%$ \\
& Livestock-Fishing & $3.3 \%$ \\
\hline & $10-15$ years & $33.3 \%$ \\
& $16-20$ years & $43.3 \%$ \\
& $21-25$ years & $23.4 \%$ \\
\hline
\end{tabular}

This aspect may be related to the conditions of the locality, which may suffer from a lack of school support, which forces most young people to seek urbanized regions in addition to being linked to the social context that predisposes women as responsible for household chores [33].

Of the interviewees, 67\% ( $\mathrm{n}=20)$ said they did not fish, and 90\% $(\mathrm{n}=27)$ did not hunt (Figures $2 \mathrm{~A}$ and $2 \mathrm{~B}$ ), but hunting practices were reported through the use of guns and dogs. Although hunting is not apparently practiced by residents, all confirmed the presence of mammal species, with emphasis on armadillos, giant anteaters, monkeys and capybaras, which were confirmed by more than $40 \%(\mathrm{n}=12)$ of interviewees (Figure $2 \mathrm{C})$. Twenty-one interviewees $(70 \%)$ said they have seen animals at least twice a week. 

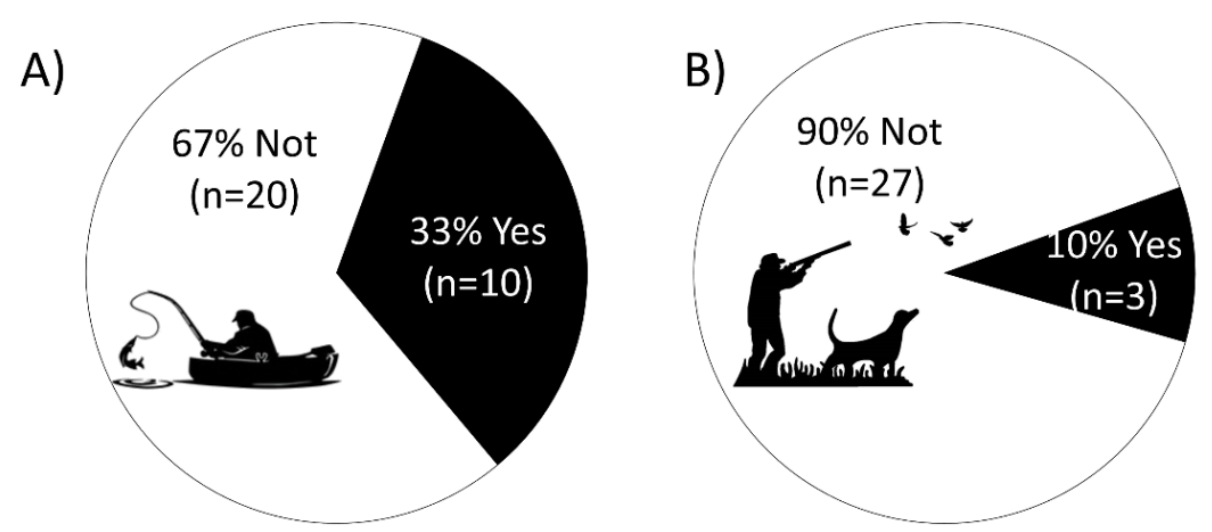

C)

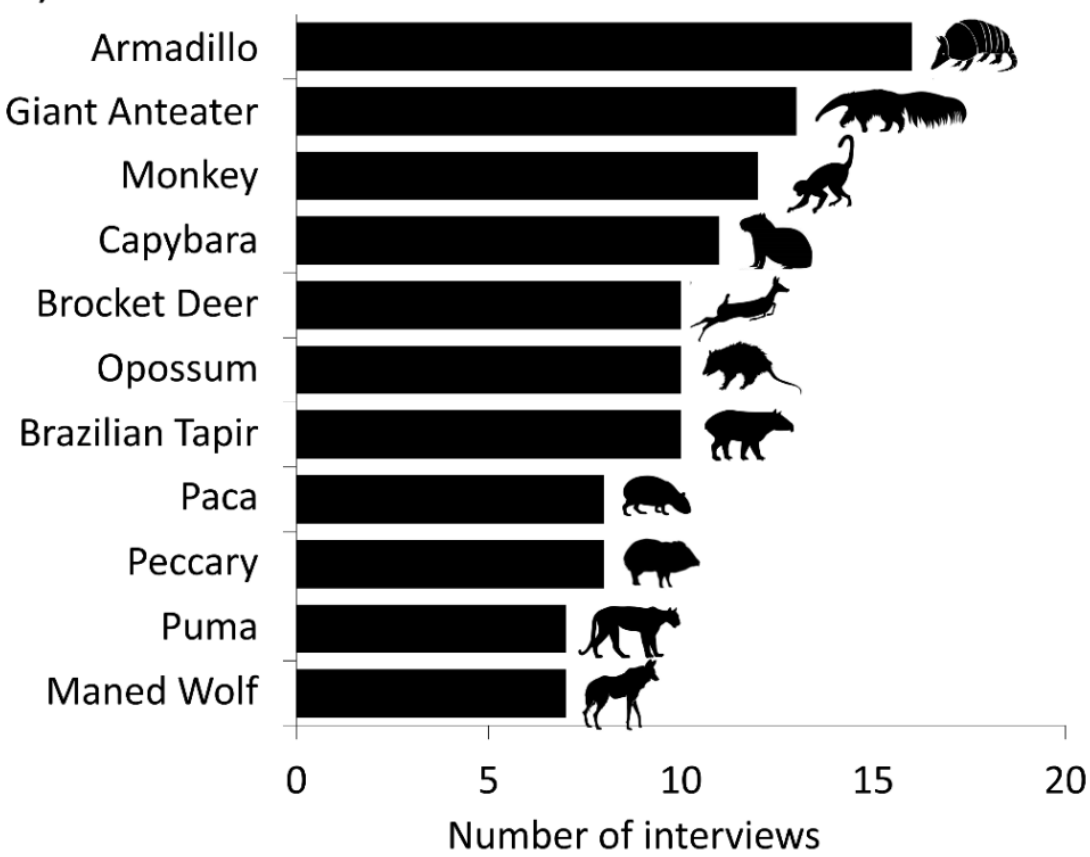

Figure 2. Number and percentage of interviewees on fishing $(A)$ and hunting $(B)$ activities in the São Domingos dos Olhos D'Água settlement. (C) Number of interviewees who said they saw species of mammals in the settlement area.

Hunting practices with guns and dogs were reported by $10 \%$ of interviewees. However, we found bullet and dogs trained during interviews in residences that did not report this practice, suggesting for us that more residents practice hunting, despite not having confirmed this behavior. The omission of hunting practice should be related to the fear of inspection agencies. The species with the highest number of records were those that adapted to modified environments, or naturally with high population density [34], although they are also hunted species. The interaction with the fauna depends on the social and cultural contexts, usually added to the use or risk that these animals can generate to a community [6].

The first axis of the PCA explained 55.3\% of the variation, and ordered the interviewees according to the perception of the presence of mammals in the SDOA settlement (Figure 3A). All mammal species in the region were viewed by at least seven interviewees, and the armadillo, anteater, monkey and capybara were viewed by at least 12 interviewees (Figure 2C and Figure 3A). We found a significant association $\left(\mathrm{R}^{2}\right.$ adj $=0.43 ; \mathrm{df}=26 ; \mathrm{p}<0.001$ ) between PC1 (axis 1 of PCA) with socioeconomic parameters, however, only monthly income $(t=-3.701 ; p=0.001)$ and the residence time in the settlement $(t=-2,390 ; p=0.024)$ were negatively related to PC1 (Figure 3B 
and 3C). Thus, the lower the monthly income and the residence time, the higher degree of perception about the mammal composition between interviewees.
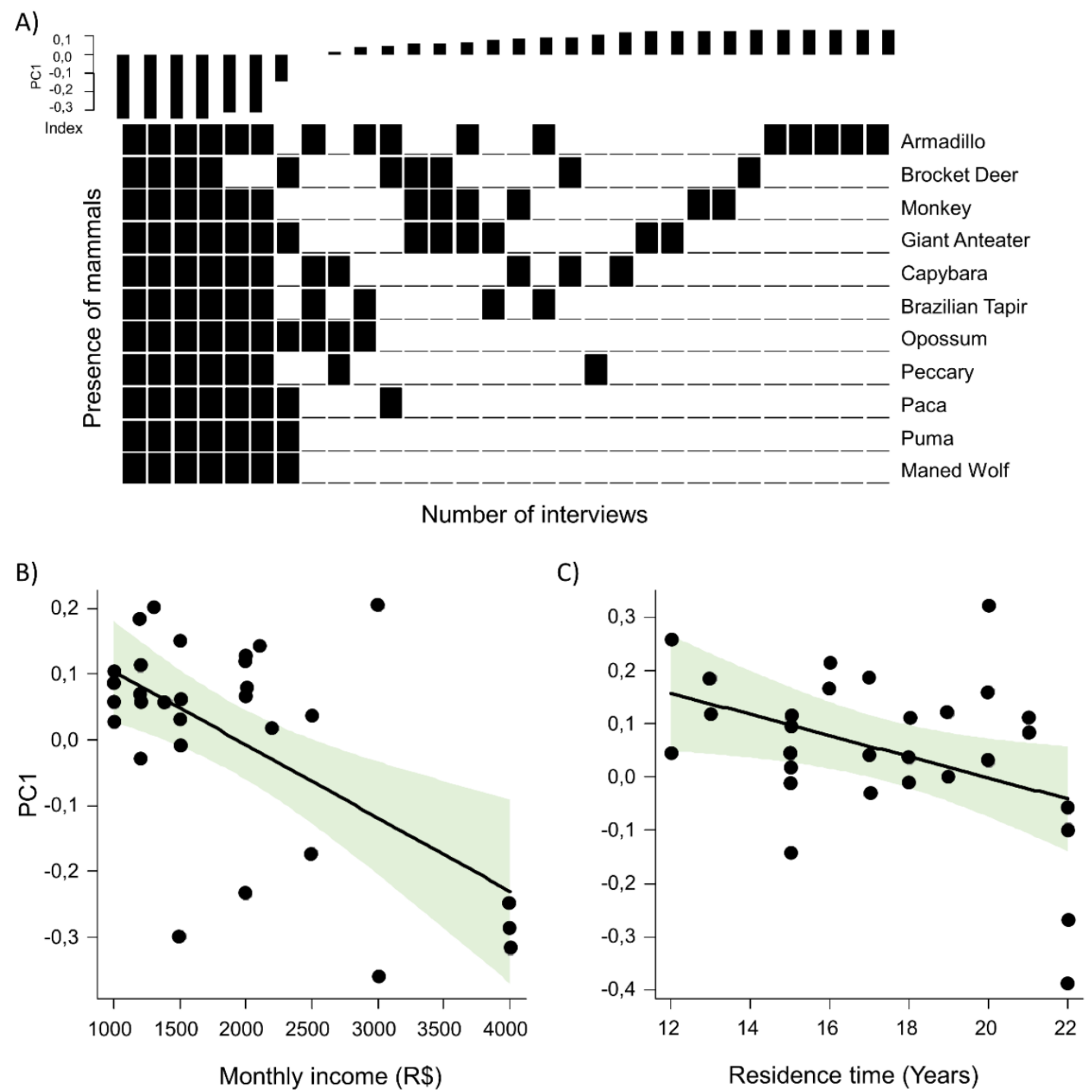

Figure 3. Presence of mammals and socioeconomic parameters of residents in the São Domingos dos Olhos D'Água settlement, central Brazil. A) Ordination of interviewees by axis 1 of the PCA according to the perception of the presence of mammals in the region. B) Relationship between monthly income and PC1. PC1 (presence of mammals), corresponds to the order of species in graph A. C) Relationship between residence time in the settlement and $\mathrm{PCl}$.

Several factors influence in the knowledge about hunting and the use of cinegetic animals [35]. In a widely context, the influence of the socioeconomic factors in relation to the use of animal as food is evident, and individuals with lower incomes often mention that they hunt for subsistence or to obtain additional income for the acquisition of essential products [e.g., clothing and tools, medicinal and magic religious purposes] for the survival of their families [36, 37]. The temporal effect recorded during interviews may have resulted in memories of sightings in the past years, but they have forgotten to report them in details. However, traditional zoological knowledge is always circumstantial and variable, changing in a quantitative and qualitative way, therefore depending on the cultural context added to each species [38]. Hence, reflections and discussions about ethnobiology created subsidies for its establishment as a scientific study area, providing discussions 
and encouraging debates related to the socioeconomic and cultural context of human and its relationship with environment. [6]. Ethnobiological studies tend to link scientific contexts and inquiries to the precedence of communities and populations that have a history of resource exploration, highlighting the interaction between the use of natural resources and conservation practices [34]. Thus, fauna studies associated with ethnozoology may contribute substantially to the establishment of species conservation because they provide information about the actual conditions of the biotic environment, linked to the variables such as monthly income and residence time which have a direct relationship in the people's perception of the presence of mammals in the SDOA settlement area.

\section{CONCLUSION}

Ethnozoology has increasingly advanced as a strong science, covering geographic and cultural gaps that have not been explored in recent years. The increase in ethnozoological studies in areas little investigated has confirmed already established patterns, but also brings new answers about human-animal interaction. In this way, inventories, monitoring studies and environmental impact associated with ethnozoology studies can contribute substantially to the establishment of species conservation, providing information about the environment and its local biodiversity. Ethnozoology can use the knowledge acquired by the systematic survey of fauna and relate it to the cultural diversity and survival needs of the local population in order to identify the animal species that suffer most from the pressure of use and trade and thus propose measures for sustainable use of the local fauna. This study demonstrated the role of ethnozoology as a systematic, quantitative and taxonomic science that uses socioeconomic and scientific data related to the perception of the local population about its fauna, contributing to the understanding of the richness, composition and conservation of mammals on regional scale.

\section{ACKNOWLEDGEMENTS}

We thank to the people residents in São Domingos dos Olhos D'Água settlement that participated to the survey. We are grateful to the Fundação de Amparo à Pesquisa do Estado de Goiás [FAPEG] for financial support given to AMVO [Process 201810267000610].

\section{REFERENCES}

1. Dirzo R, Young HS, Galetti M, Ceballos G, Isaac NJB, Collen B. Defaunation in the Anthropocene. Science. 2014;345(6195):401-6, doi: 10.1126/science.1251817

2. Haddad NM, Brudvig LA, Clobert J, Davies KF, Gonzalez A, Holt RD, et al. Habitat fragmentation and its lasting impact on Earth's ecosystems. Sci Adv. 2015;1(2):1-9.

3. Newbold T, Hudson LN, Hill SLL, Contu S, Lysenko I, Senior RA, et al. Global effects of land use on local terrestrial biodiversity. Nature. 2015;520(7545):45-50, doi: 10.1038/nature14324

4. Liu J, Wilson M, Hu G, Liu J, Wu J, Yu M. How does habitat fragmentation affect the biodiversity and ecosystem functioning relationship? Landsc Ecol. 2018; 33(3): 341-52, doi: 10.1007/s10980-018-0620-5

5. Alves RRN. Relationships between fauna and people and the role of ethnozoology in animal conservation. Ethnobiol Conserv. 2012;1(2012):1-69, doi: 10.15451/ec2012-8-1.2-1-69

6. Alves RRN, Souto WMS. Ethnozoology: A brief introduction. Ethnobiol Conserv. 2015;4:1-13.

7. de Lima JRB, Florêncio RR, Santos CAB. Contribuições da Etnozoologia para a conservação da fauna silvestre. Rev Ouricuri. 2014;4(3):48-67, doi: 10.15451/ec2015-1-4.1-1-13

8. Joa B, Winkel G, Primmer E. The unknown known - A review of local ecological knowledge in relation to forest biodiversity conservation. Land Use Policy. 2018;79:520-30, doi: 10.1016/j.landusepol.2018.09.001

9. Alves RRN, Souto WMS. Ethnozoology in Brazil: Current status and perspectives. J Ethnobiol Ethnomed. 2011;7:22, doi: 10.1186/1746-4269-7-22

10. Myers N, Mittermeier RA, Mittermeier CG, Fonserca GAB, Kent J. Biodiversity hotspots for conservation priorities. Nature. 2000;403:853-8. 
11. IBGE. Instituto Brasileiro de Geografia e Estatística [Internet]. Brasil: IBGE; 2020 [cited 2020 Oct 22]. Available from: https://www.ibge.gov.br/

12. ICMBio. Biodiversidade Portal (PortalBio). Brasília (DF): Instituto Chico Mendes; 2020 [cited 2020 Oct 22]. Available from: https://www.portaldabiodiversidade.icmbio.gov.br/portal/

13. Joly CA, Scarano FR, Bustamante M, Gadda TMC, Metzger JPW, Seixas CS, et al. Brazilian assessment on biodiversity and ecosystem services: Summary for policy makers. Biota Neotrop. 2019;19(4): e20190865, doi: 10.1590/1676-0611-BN-2019-0865

14. Mittermeier RA, Gil PR, Hoffmann M, Pilgrim J, Brooks T, Mittermeier CG, et al. Hotspots revisited: Earth's biologically richest and most endangered ecoregions. Mexico City (Mexico): CEMEX; 2004. 390 p.

15. Júnior AP, Pereira ER. Degradação ambiental e a diversidade biológica/biodiversidade: uma revisão integrativa. Enciclopédia Biosf. 2017;14(26):530-43.

16. Paglia AP, Fonseca GAB, Rylands B, Herrmann G, Aguiar LMS, Chiarello AG, et al. Lista anotada dos mamíferos do Brasil. 2. ed. Occasional Papers in Conservation Biology, n. 6. Arlington (US): Conservation International, VA; $2012.76 \mathrm{p}$.

17. Gutierrez EE, Marinho-Filho J. The mammalian faunas endemic to the Cerrado and the Caatinga. Zookeys. 2017;644:105-57, doi: 10.3897/zookeys.644.10827

18. Camargo FF, de Souza TR, da Costa RB. Etnoecologia e etnobotânica em ambientes de Cerrado no Estado de Mato Grosso. Interações. 2014;15(2):353-60.

19. Alves RRN, Rosa IL. Why study the use of animal products in traditional medicines? J Ethnobiol Ethnomed. 2005;1(1):1-5, doi: 10.1186/1746-4269-1-5

20. dos Santos MJ, Pontes AE. Desenvolvimento local, reforma agrária e ocupação territorial: o caso do Assentamento São Domingos dos Olhos D'água. Rev Campo-Território. 2016;11(22):311-40.

21. Hannibal W, Duarte LA, Santos CC. Mamíferos não voadores do Pantanal e entorno. Campo Grande (MS): Natureza em Foco; 2015. 214 p.

22. ICMBio/MMA. Livro Vermelho da Fauna Brasileira Amaeaçada de Extinção, Volume II - Mamíferos. 1. ICMBio, editor. Brasília (DF): Instituto Chico Mendes de Conservação da Biodiversidade; 2018. 622 p.

23. IUCN. The IUCN Red List of Threatened Species. v. 2020-2. [place unknown]: IUCN; 2020 [cited 2020 Oct 1]. p. 2020-2. Available from: https://www.iucnredlist.org/

24. Pasa MC. Etnobiologia de uma comunidade Ribeirinha no Alto da Bacia do Rio Aricá Açu, Cuiabá, Mato Grosso, Brasil [PhD thesis]. São Carlos (SP): Universidade Federal de São Carlos; 2004. 174 p.

25. Oksanen J, Blanchet FG, Friendly M, Legendre RKP, McGlinn D, Minchin PR, et al. vegan: Community Ecology Package. R package version 2.5-6. R Core Team. 2019. Available from: https://cran.rproject.org/package $=$ vegan

26. R Core Team. R: A language and environment for statistical computing. v. 4.0.2. Vienna (Austria): R Foundation for Statistical Computing; 2019. Available from: https://www.r-project.org/

27. Jones KE, Safi K. Ecology and evolution of mammalian biodiversity. Philos Trans R Soc B Biol Sci. 2011;366(1577):2451-61, doi: 10.1098/rstb.2011.0090

28. dos Reis NR, Peracchi AL, Pedro WA, Lima IP. Mamíferos do Brasil. 2nd ed. dos Reis NR, Peracchi AL, Pedro WA, Lima IP, editors. Curitiba (PR): Nélio Roberto dos Reis; 2011. 439 p.

29. Miranda FR, Chiarello AG, Röhe F, Braga FG, Mourão GM, de Miranda GHB, et al. Myrmecophaga tridactyla Linnaeus, 1758. In: ICMBio/MMA, editor. Livro vermelho da fauna brasileira ameaçada de extinção - Volume II - Mamíferos. 2. ed. Brasília (DF): MMA; 2018. p. 40-6.

30. de Paula RC, Rodrigues FHG, Diego Queirolo RPSJ, Lemos FG, Rodrigues LA. Chrysocyon brachyurus (Illiger, 1815). In: ICMBio/MMA, editor. Livro vermelho da fauna brasileira ameaçada de extinção Volume II - Mamíferos. 2 ed. Brasília (DF): MMA; 2018. p. 314-9.

31. de Azevedo FC, Lemos FG, de Almeida LB, de Campos CB, Beisiegel BM, de Paula RC, et al. Puma concolor (Linnaeus, 1771). In: ICMBio/MMA, editor. Livro vermelho da fauna brasileira ameaçada de extinção - Volume II - Mamíferos. 2. ed. Brasília (DF): MMA; 2018. p. 358-65.

32. Medici EP, Flesher K, Beisiegel BM, Keuroghlian A, Desbiez ALJ, Gatti A, et al. Tapirus terrestris (Linnaeus, 1758). In: ICMBio/MMA, editor. Livro vermelho da fauna brasileira ameaçada de extinção Volume II - Mamíferos. 2. ed. Brasília (DF): MMA; 2018. p. 59-67.

33. Pires MRS, Pinto LCL, de Figueiredo MRO. Percepção ambiental sobre o conhecimento popular de moradores rurais relativo as serpentes e acidentes ofídicos. Educ Ambient Ação. 2018;12(45): [about 9 screens]. Available from: http://www.revistaea.org/artigo.php?idartigo=1615

34. Oliveira VB, Câmara EMVC, Oliveira LC. Composição e caracterização da mastofauna de médio e grande porte do Parque Nacional da Serra do Cipó, Minas Gerais, Brasil. Mastozool Neotrop. 2009;16(2):355-64.

35. Bennett EL, Robinson JG. Hunting of Wildlife in Tropical Forests: Implications for Biodiversity and forest peoples. Washington (US): The Wildlife Conservation Society; 2000. 42 p. 
36. Alves RRN, Gonçalves MBR, Vieira WLS. Caça, uso e conservação de vertebrados no semiárido Brasileiro. Trop Conserv Sci. 2012;5(3):394-416.

37. de Lima RJP, Barbosa EDO, Chaves MF. Hunting activities in the semiarid potiguar under the students perspective. Ambiente Soc. 2018;21: e00192, doi: 10.1590/1809-4422asoc0019r2vu1814ao

38. Santos-fita D, Costa-Neto EM. As interações entre os seres humanos e os animais: a contribuição da etnozoologia. Biotemas. 2007;20(4):99-110. 
Appendix 1. Socioeconomic interview.

1. What is your age group?

2. What is the family income

3. How many people live in the residence?

4. What is your education level?

[ ] incomplete elementary school

[ ] complete primary education

[ ] incomplete high school

[ ] complete high school

[ ] incomplete higher education

[ ] complete higher education

5. What is the main activity of the family?

[ ] agriculture

[ ] livestock

[ ] hunting

[ ] fishing

[ ] others. Which one?

6. What region did the family come from?

7. How long is the settlement?

8. How many people in the family group work and have an income? 
Appendix 2. Ethnozoological questionnaire.

1. Does the family use fishing?

[ ] No [ ] Yes. How many times a week?

2. Does the family use hunting?

[ ] No [ ] Yes. Which species?

3. What instruments do you use for hunting and fishing?

4. Which or which of the animals below have you seen in the settlement?

[ ] tapir [ ] cateto [ ] capybara [ ] skunk [ ] maned wolf

[ ] monkey [ ] jaguar [ ] paca [ ] giant anteater [ ] armadillo [ ] deer

[ ] Others

5. What is the frequency of viewing animals with fur?

[ ] up to twice a week

[ ] up to three times a week

[ ] more than four per week

6. Has the number of animals seen, like monkeys, decreased in the last year?

[ ] No [ ] Yes [ ] I don't know

Which animal 